\title{
IMPLIKASI PELAKSANAAN PEMILIHAN KEPALA DAERAH (PILKADA) SECARA SERENTAK TERHADAP ASPEK SOSIAL, POLITIK, DAN EKONOMI ${ }^{1}$
}

\author{
Achmad Zulfikar \\ Magister Ilmu Politik, Universitas Hasanuddin \\ apa@kabarfikar.com \\ Baharuddin Nur \\ Wakil Pemimpin Umum Majalah Suara Gubernur \\ ben@suaragubernur.com
}

\begin{abstract}
Local election / regional head election is antithesis of appointment of region head which have lasted long enough, at least almost as old with Old Order Era plus with New Order Era or about 50 year from 70 year old of Indonesian was established. Appointment and election are two different things. Elected is certainly more democratic than appointed. Elected is the result of a number of alternatives, while being lifted is more impressed with a choice that comes from the top. Local election is a system built by the government to ensure the Regional Head comes from the people's choice, not the appointment of officials or powers above it. Typically, elections take place in accordance with the political activities of each region, where the five-year term is used as a benchmark for the implementation of re-elections. However, on December 9, 2015 this calendar has changed based on the consideration of efficiency and effectiveness of Local election implementation in the future. Therefore, the elections that will take place in Indonesia is the biggest democracy party ever conducted in this country, even in the world. In this paper, the authors challenged to examine how the possibilities would arise as the implications of this Local concurrent election on the social, political and economic aspects of society in Indonesia.
\end{abstract}

Keywords: Implication, Local Concurrent Election, Social, Political, Economic

\begin{abstract}
Abstrak
Pemilihan Kepala Daerah (Pilkada) adalah antitesa dari pengangkatan kepala daerah yang telah berlangsung cukup lama, setidaknya hampir seusia dengan orde lama ditambah orde baru atau sekitar 50 tahun dari 70 tahun usia pemerintahan kita. Diangkat dan dipilih adalah dua hal yang berbeda. Dipilih tentu saja lebih demokratis daripada diangkat. Dipilih merupakan hasil dari sejumlah alternatif, sementara diangkat lebih terkesan suatu pilihan yang datang dari atas (top down). Pilkada merupakan sistem yang dibangun oleh pemerintah untuk memastikan Kepala Daerah berasal dari pilihan rakyat, bukan penunjukan dari pejabat atau kekuasaan diatasnya. Lazimnya, Pilkada berlangsung sesuai dengan penanggalan kegiatan politik setiap daerah, dimana batas masa tugas lima tahun dijadikan sebagai patokan untuk dilaksanakannya Pilkada lagi. Namun pada 9 Desember 2015 ini penanggalan itu mengalami perubahan atas dasar pertimbangan efisiensi dan efektivitas pelaksanaan Pilkada ke depan. Oleh karenanya, Pilkada yang akan berlangsungi di Indonesia ini merupakan pesta demokrasi terbesar yang pernah dilakukan di negeri ini, bahkan di dunia. Dalam makalah ini, penulis tertantang untuk menelaah bagaimana kemungkinan yang akan timbul sebagai implikasi Pilkada serentak ini terhadap aspek sosial, politik dan ekonomi masyarakat di Indonesia.
\end{abstract}

Kata Kunci: Implikasi, Pilkada Serentak, Sosial, Politik, Ekonomi

\footnotetext{
${ }^{1}$ Makalah dipresentasikan dalam Seminar Nasional Menyongsong Pilkada Serentak yang diselenggarakan oleh Program Studi (S1 \& S2) Ilmu Politik Universitas Hasanuddin bekerjasama dengan Dewan Kehormatan Penyelenggara Pemilu (DKPP) RI, Komisi Pemilihan Umum (KPU) RI, Badan Pengawas Pemilihan Umum (Bawaslu) RI dan Asosiasi Ilmu Politik Indonesia (AIPI) Pengurus Cabang Kota Makassar pada 10 November 2015.
} 


\section{Pendahuluan}

Dirilis dalam situs Komisi Pemilihan Umum (KPU) (http://www.kpu.go.id/) secara resmi terdaftar 810 pasangan cal’on (paslon) kepala daerah yang terdiri atas calon Gubernur, Bupati dan Walikota yang akan berkompetisi merebut suara pemilih pada 9 Desember mendatang. Diantara 810 pasangan tersebut, terdapat 654 paslon melalui jalur partai politik, sementara sisanya (156 paslon) melalui jalur perseorangan (independen). Di antara keseluruhan paslon tersebut terdapat 164 petahana (incumbent).

Data yang dirilis oleh KPU di atas sepintas hanyalah angka-angka tabulatif yang bisa dilihat sebagai indikator daya tarik posisi kepala daerah, baik Gubernur, Bupati maupun walikota bagi masyarakat Indonesia. Setidaknya ada 810 pasangan (1620 orang) yang memperebutkan 268 kursi (Gubernur, Bupati dan Walikota). Rasio yang relatif kecil dimana secara kalkulasi satu berbanding sekitar 3,5. Bandingkan dengan rasio perebutan rata-rata kursi legislatif yang mencapai 1:12. Berapa jumlah orang yang kemungkinan frustrasi, depresi, mengalami gangguan jiwa akibat kehilangan peluang, harta benda, harga diri dan lain-lain akibat gagal men dapatkan kursi yang diimpikan? Belum ada data resmi, tetapi dapat diyakini bahwa keadaan itu ada dengan kadar yang berbeda-beda.

Itulah bentuk implikasi yang penulis maksudkan, namun dalam tulisan ini implikasi yang penulis maksud adalah akibat penyelenggaraan Pilkada Serentak dibanding dengan Pilkada yang tidak serentak. Yang terpapar saat ini adalah bahwa perhatian dan perbincangan masyarakat tentang Pilkada yang terpantau melalui media sosial tidak setajam pada pilkada tunggal. Asumsi yang dapat dikemukakan adalah, pertama, bahwa tidak tajamnya perbedaan atau konfrontasi antar pendudkung di media sosial dikarenakan terpecahanya focus pada berbagai isu pilkada di tempat lain. Kedua, kemungkinan dikarenakan masyarakat mengalami keterkejutan (shock) akibat pertama kali menghadapi suasana dan situasi pilkada yang tidak biasa.

Keterlibatan masyarakat dalam memilih pemimpin di daerah masing-masing berawal di tahun 2005 ketika bangsa Indonesia memulai era baru dalam penyelenggaraan tata pemerintahan di tingkat lokal. Kepala daerah, baik bupati/walikota maupun gubernur yang sebelumnya dipilih secara tidak langsung oleh DPRD, sejak Juni 2005 dipilih secara langsung oleh rakyat melalui proses pemilihan kepala daerah yang sering disingkat dengan Pilkada.Pemilihan Kepala Daerah dan Wakil Kepala Daerah secara langsung diatur dalam undang-undang nomor 32 tahun 2004 
tentang Pemerintah Daerah yang lebih spesifik di atur dalam bagian tata cara pemilihan, Pengesahan, Pengangkatan, dan Pemberhentian Kepala Daerah dan Wakil Kepala Daerah.

Pilkada langsung merupakan koreksi atas pilkada terdahulu yang menggunakan sistem perwakilan oleh DPRD (Dewan Perwakilan Rakyat Daerah). Digunakannya sistem pemilihan langsung menunjukkan perkembangan demokrasi yang semakin matang di tingkat daerah. Pilkada langsung dinilai sebagai perwujudan pengembalian hak-hak dasar masyarakat di daerah dengan memberikan kewenangan yang utuh dalam rangka rekrutmen pimpinan daerah sehingga mendorong dinamika dalam kehidupan demokrasi di tingkat lokal. Keberhasilan pilkada langsung untuk melahirkan pemimpin daerah yang demokratis, sesuai kehendak dan tuntutan rakyat sangat bergantung pada daya kritis dan rasionalitas pemilih/rakyat itu sendiri.

Selanjutnya, sejak Undang-Undang Nomor 22 Tahun 2007 tentang Penyelenggara Pemilihan Umum berlaku pilkada dimasukkan dalam rezim pemilu, sehingga secara resmi bernama Pemilihan umum Kepala Daerah dan Wakil Kepala Daerah atau disingkat Pemilukada. Pemilukada pertama yang diselenggarakan berdasarkan undang-undang ini adalah Pilkada DKI Jakarta 2007. Kemudian, pada tahun 2011, terbit undang-undang baru mengenai penyelenggaraan pemilihan umum yaitu Undang-Undang Nomor 15 Tahun 2011. Di dalam undang-undang ini, istilah yang digunakan adalah Pemilihan Gubernur, Bupati, dan Wali Kota.

Pada tahun 2014, Pilkada secara langsung sempat mengalami kegentingan. Dewan Perwakilan Rakyat Republik Indonesia (DPR RI) mengangkat isu krusial terkait Pilkada secara langsung. Sidang Paripurna DPR RI pada tanggal 24 September 2014 memutuskan bahwa Pilkada dikembalikan secara tidak langsung, atau kembali dipilih oleh DPRD. Putusan Pemilihan kepala daerah tidak langsung didukung oleh 226 anggota DPR-RI yang terdiri Fraksi Partai Golkar berjumlah 73 orang, Fraksi Partai Keadilan Sejahtera (PKS) berjumlah 55 orang, Fraksi Partai Amanat Nasional (PAN) berjumlah 44 orang, dan Fraksi Partai Gerindra berjumlah 32 orang.

Keputusan ini telah menyebabkan beberapa pihak kecewa. Keputusan ini dinilai sebagai langkah mundur di bidang "pembangunan" demokrasi, sehingga masih dicarikan cara untuk menggagalkan keputusan itu melalui uji materi ke MK (Mahkamah Konstitusi). Pro dan kontra terkait Pilkada langsung maupun tidak langsung menyebabkan Presiden Republik Indonesia saat itu Susilo Bambang Yudhoyono mengambil langkah penyelamatan setelah mendapatkan desakan dari rakyat dengan diterbitkannya Peraturan Pemerintah Pengganti Undang-Undang (Perpu) No. 
1 Tahun 2014. Peraturan ini menjadi landasan yuridis untuk mengembalikan hak pilih ke tangan rakyat.

Pengesahan Perpu ini juga berimplikasi terhadap pelaksanaan Pilkada serentak yang telah bergulir sebelum aturan ini disahkan dan semakin menguat. Maka, Perpu ini menjadi landasan hukum (yuridis) bagi pelaksanaan Pilkada serentak. Perpu No. 1 Tahun 2014 ini kemudian disahkan oleh DPR RI dengan menerbitkan UU No. 8 Tahun 2015 tentang Perubahan Atas UU No. 1 Tahun 2015 tentang Penetapan Peraturan Pemerintah Pengganti Undang-Undang No. 1 Tahun 2014 tentang Pemilihan Gubernur, Bupati dan Walikota menjadi Undang-Undang.

Dalam UU No. 8 Tahun 2015 Pasal 201 ayat 1 jelas menyebutkan bahwa pemungutan suara serentak dalam Pemilihan Gubernur dan Wakil Gubernur, Bupati dan Wakil Bupati, serta Walikota dan Wakil Walikota yang masa jabatannya berakhir pada tahun 2015 dan bulan Januari sampai dengan bulan Juni tahun 2016 dilaksanakan pada tanggal dan bulan yang sama pada bulan Desember tahun 2015.

Dalam draft Rancangan UU No. 8 tahun 2015 tentang Perubahan Atas UU No. 1 Tahun 2015 tentang Penetapan Perpu No. 1 Tahun 2014 tentang Pemilihan Gubernur, Bupati dan Walikota dinyatakan bahwa Pilkada serentak dijadwalkan tiga gelombang pada 2015 dan 2018 untuk kepala daerah yang habis masa jabatannya pada kurun waktu itu, kemudian pilkada nasional serentak pada 2020.

Namun saat pembahasan RUU No. 8 Tahun 2015 tersebut disepakati gelombang pelaksanaan Pilkada serentak menjadi tujuh gelombang yakni: (1) gelombang pertama dilaksanakan pada Desember 2015 untuk kepala daerah yang masa jabatannya berakhir pada 2015 serta pada semester pertama 2016; (2) gelombang kedua akan dilaksanakan pada Februari 2017 untuk kepala daerah yang masa jabatannya berakhir pada semester kedua 2016 dan kepala daerah yang masa jabatannya berakhir pada 2017.

Selanjutnya, (3) gelombang ketiga akan dilaksanakan pada Juni 2018 untuk kepala daerah yang masa jabatannya berakhir pada 2018 dan 2019; (4) gelombang keempat akan dilaksanakan pada 2020 untuk kepala daerah hasil pemilihan Desember 2015; (5) gelombang kelima akan dilaksanakan pada 2022 untuk kepala daerah hasil pemilihan pada Februari 2017; (6) gelombang keenam akan dilaksanakan pada 2023 untuk kepala daerah hasil pemilihan 2018. Kemudian, (7) gelombang ketujuh dilakukan pilkada serentak secara nasional pada 2027. Jadi mulai 2027, pilkada dilakukan secara serentak di seluruh provinsi, kabupaten, dan kota di Indonesia, untuk 
seterusnya dilakukan kembali tiap lima tahun sekali. Pilkada tujuh gelombang inilah yang disepakati dan disahkan dalam Undang-Undang Nomor 8 Tahun 2015.

\section{Pembahasan}

\section{Implikasi Sosial}

Menurut catatan Kementerian Dalam Negeri (Kemendagri), sejak pilkada langsung digelar pertama kali pada 2005 hingga Agustus 2013, tercatat 75 orang meninggal dan 256 lainnya cedera sebagai akibat ekses langsung dari sejumlah bentrokan yang mengiringi penyelenggaraan Pilkada di sejumlah daerah. Kerugian fisik dalam bentuk kerusakan infrastruktur dan sarana umum juga tak kalah banyaknya, termasuk harta benda individu yang rusak saat terjadinya bentrokan antar pendukung.

Keadaan yang meresahkan seperti disebutkan di atas terasa makin sering terjadi di sekitar kita akibat pemberitaan yang tidak putus dari waktu ke waktu. Dengan waktu pelaksanaan yang berbeda-beda tersebut berpotensi menciptakan keresahan sosial yang berantai yang akan mengganggu kenyamanan hidup rakyat yang terpapar berita-berita kekerasan yang menyertai pelaksanaan Pilkada di sejumlah daerah yang diselenggarakan dalam waktu yang berbeda-beda.

Bayangkan, dengan 33 provinsi dan 492 kabupaten/kota yang harus melaksanakan pilkada setiap lima tahun untuk memilih kepala daerah masing-masing, seberapa sering peristiwa Pilkada yang harus terjadi di negeri ini dalam setahun. Jika dihitung kasar dengan mengesampingkan Provinsi DI Yogyakarta yang tidak melaksanakan pemilihan gubernur, maka setiap lima tahun ada 525 pelaksanaan Pilkada. Artinya, dalam setahun ada sedikitnya 130 peristiwa Pilkada atau setiap empat hari digelar Pilkada di Tanah Air. Setiap peristiwa Pilkada pasti menyita perhatian media nasional apalagi media daerah, baik cetak, elektronik maupun online.Pemberitaan dimulai dari penjaringan bakal calon, pendaftaran, kampanye tertutup, kampanye terbuka, hari pemungutan suara, perhitungan suara, sengketa, penyelesaian sengketa hingga pelantikan. Pada setiap tahap berpotensi menimbulkan pergesekan bahkan bentrok diantara masyarakat yang loyal kepada kandidat yang didukungnya.

Peristiwa Pilkada memang berbeda dengan peristiwa yang lain seperti seminar, pameran, gelar budaya dan semacamnya, seberapapun besarnya. Tetapi pemilihan yang bernuansa politis pasti memiliki potensi konflik yang tinggi. Tanpa bermaksud membandingkan, pemilihan kepala desa patut dijadikan contoh bagaimana konflik antar pendukung kandidat di dalam suatu desa 
bisa memicu tindakan kriminal dan perbuatan melawan hukum lainnya apalagi Pilkada yang skalanya lebih besar. Pilkada pasti sarat dengan beragam kepentingan yang tentu saja potensi konfliknya, baik horizontal maupun konflik vertikal lebih besar potensinya untuk terjadi.

Berita kekerasan akibat bentrok antar pendukung, money politic, korupsi, fitnah dari kampanye gelap, pembodohan, umbar janji bohong dan sebagainya adalah peristiwa yang diberitakan secara intensif yang bahkan memaksa anak didik yang terpapar berita seperti itu tanpa sengaja melalui televisi harus bertanya mengenai arti semua itu kepada orangtua mereka. Pemberitaan negatif yang terus menerus dikonsumsi masyarakat cenderung akan membuat mereka kebal alias permisif dan menganggap sogokan, korupsi, saling fitnah dan semacamnya sebagai hal yang biasa dan tidak perlu dipermasalahkan.

\section{Implikasi Politik}

Implikasi politik penyelenggaraan Pilkada serentak setidaknya akan mengurangi dominasi partai politik besar dalam melaksanakan kampanye di daerah. Jika sebelumnya pentolan partai suka melakukan kampanye keroyokan di daerah untuk mendukung kandidat dari partainya, maka dengan Pilkada serentak mereka harus berhitung logistik dan tentu saja harus lebih arif mempertimbangkan mitra koalisinya agar tidak mengesankan inkonsistensi yang akan menurunkan elektabilitas kandidat yang didukungnya.

Penjelasannya, bahwa tidak selalu partai politik berkoalisi permanen dengan sejumlah partai tertentu dalam mendukung kandidat di setiap propinsi, bahkan nasional. Bisa jadi Partai Politik A berkoalisi dengan Parpol B dan C untuk mendukung calon yang sama di Kabupaten Y, tetapi di Kabupaten W Parpol A berseberangan dukungan dengan Parpol B atau C sehingga bila Parpol A mencederai Parpol lainnya di suatu Kabupaten bisa berimplikasi buruk terhadap soloditas Parpol mereka di Kabupaten lainnya.

Oleh karenanya, konstelasi pilihan kendaraan parpol setiap kandidat Kepala Daerah di setiap daerah tidak bisa lagi seperti sebelumnya dimana selalu mempertimbangkan kebesaran nama partainya karena dengan Pilkada serentak mesin politik besar sekalipun tidak bisa maksimal diarahkan ke satu titik melainkan harus melayani sejumlah titik lainnya dalam waktu yang bersamaan. Kondisi seperti ini tentu saja akan menguntungkan calon kepala daerah dari jalur independen karena akan menghadapi kandidat yang didukung parpol yang makin lemah dukungannya karena harus menyebarkan sumberdaya mereka di Pilkada serentak ini. Sejumlah 
pengamat meramalkan bahwa Pilkada serentak akan banyak dimenangkan oleh calon independen karena lebih solid dibanding calon dari parpol.

Setelah Pilkada serentak tahap pertama ini, dipastikan akan terjadi perubahan konstelasi politik dalam urusan dukungan terhadap kandidat. Sekali suatu parpol menurun elektabilitasnya secara nasional akibat satu dan lain hal termasuk perilaku pengurusnya, maka dapat dipastikan parpol tersebut juga akan berkurang manfaatnya dalam memberikan dukungan bagi kandidat yang didukungnya dan mereka tidak memiliki cukup waktu untuk melakukan pemulihan atau recovery kecuali harus menunggu Pilkada serentak berikutnya. Kondisi ini yang akan mendorong setiap calon pada Pilkada serentak berikutnya lebih memperkuat ketokohan dan popularitasnya di tingkat wilayah masing-masing daripada mengharapkan keuntungan dengan mencantolkan diri kepada partai besar. Bila ketokohan dianggap lebih menguntungkan untuk dikedepankan dalam Pilkada serentak maka dapat dipastikan bahwa tokoh-tokoh terbaik di daerah akan semakin banyak yang meminati jalur independen, apalagi tidak perlu menyiapkan biaya "kendaraan" kepada partai yang ditumpangi.

Analisis di atas sekaligus menjelaskan bahwa kalaupun tokoh-tokoh terbaik di daerah yang akan bertarung dalam Pilkada serentak memilih partai politik sebagai kendaraan, bisa dipastikan mereka akan bernegosiasi untuk tidak membayar biaya "kendaraan". Bagi partai politik yang bersedia menampung kandidat calon kepala daerah tanpa bayaran dapat diasumsikan bahwa parpol yang demikian itu lebih baik integritasnya dibanding parpol yang masih mengandalkan biaya "kendaraan" untuk mengisi pundi-pundi partainya. dipilih menjadi modal untuk maju sebagai kandidat dibayangkan Akibat banyaknya pemberitaan peristiwa yang menyertai penyelenggaraan Pilkada selama ini, boleh dikatakan wajar jika ada kalangan yang mendesak agar sistem pilkada di Indonesia dikaji ulang dengan tetap mempertahankan azas-azas berdemokrasi yang baik yang telah diterima baik oleh masyarakat selama ini.

\section{Implikasi Ekonomi}

Secara matematis bisa dirumuskan bahwa biaya bisa berbanding lurus dengan intensitas belanja, dengan asumsi nilai belanja relatif sama pada setiap kesempatan berbelanja. Artinya bahwa semakin sering melakukan Pilkada dengan biaya yang sama pada setiap penyelenggaraan maka akan semakin tinggi biayanya dibanding melakukannya sekaligus meskipun dengan konsekuensi volume meningkat. Penyelenggaraan pemilihan kepala daerah yang begitu sering di 
Indonesia dinilai sejumlah pengamat sangat memboroskan anggaran daerah. Akibat harus membiayai Pilkada yang anggarannya dibebankan kepada Anggaran Pendapatan dan Belanja Daerah (APBD) masing-masing pada akhirnya akan mengurangi kemampuan pembiayaan daerah untuk sektor lain yang boleh jadi lebih penting dari Pilkada itu sendiri.

Sekretaris Jenderal Forum Indonesia Untuk Transparansi mengemukakan selisih 7 trilliun bila Pilkada dilakukan serentak dibanding secara parsial. Asumsinya, bila biaya Pilkada untuk Kabupaten/ Kota rata-rata sebesar Rp. 25 milliar dan untuk Propinsi Rp. 100 milliar, maka secara keseluruhan totalnya Rp. 17 trilliun. Dengan mengeluarkan semua biaya yang berulang dan berhimpit bila Pilkada dilakukan serentak, diperoleh angka Rp. 10 trilliun, artinya bisa dihemat sekitar Rp. 7 trilliun. Dengan besaran biaya tersebut dibanding ketersediaan APBN yang sekitar Rp. 2.039 trilliun, maka tentunya akan lebih baik bila pemerintah memikul beban biaya Pilkada tersebut ke dalam APBN sebagai bagian dari biaya pelaksanaan tanggungjawab negara menyelenggarakan kehidupan berdemokrasi yang lebih baik.

Contoh tentang bagaimana biaya bisa dihemat adalah melalui percetakan foto pasangan calon di dalam suatu wilayah Propinsi. Bila penyelenggaraan sendiri-sendiri, maka kertas pencoblosan hanya akan berisi beberapa pasang foto kandidat. Biaya kertas adalah komponen terbesar dalam Pilkada. Bila serentak secara propinsi, maka satu kertas suara bisa berisi sejumlah pasang foto kandidat bupati/ walikota dan calon gubernur. Cara ini sangat menghemat penggunaan kertas, apalagi bila teknologi elektronik layar sentuh bisa diterapkan, pasti akan jauh lebih hemat lagi.

Pada sisi lain implikasi ekonomi dapat dicermati dari perspektif pengusaha pemasok logistik Pilkada. Bila semakin sering Pilkada diselenggarakan maka pengusaha yang berhubungan dengan penyediaan logistik pemilu akan semakin banyak mendapatkan pekerjaan yang tentu saja akan mendapatkan keuntungan yang lebih besar. Ini tentu saja beraku bagi pengusaha yang berada di level yang lebih tinggi misalnya yang berada di propinsi yang dapat mencakup pasokan ke sejumlah Kabupaten/ Kota atau pengusaha nasional yang mencakup pasokan logistik pilkada ke sejumlah provinsi. Efek berganda (Multiplier effect) yang ditimbulkan oleh banyaknya uang beredar untuk menunjang Pilkada merupakan implikasi positif dimana belanja masyarakat yang mendapatkan upah dari pekerjaan penyediaan logistik atau mendapatkan bayaran jasa sebagai penunjang Pilkada akan meningkat. Peningkatan pendapatan masyarakat akan memicu peningkatan daya beli mereka terhadap komoditas lainnya seperti kebutuhan dapur, transportasi dan lain-lain. 


\section{Kesimpulan}

Dari paparan di atas dapat disimpulkan bahwa pelaksanaan Pilkada serentak diasumsikan akan membawa implikasi positif dan negatif terhadap aspek sosial, politik dan ekonomi para pelaku politik dan masyarakat pada umumnya. Asumsi ini dapat dibuktikan melalui riset setelah pelaksanaan pilkada serentak nanti dengan mengambil perbandingan keadaan sosial politik dan ekonomi para pelaku politik dan masyarakat pada Pilkada yang tidak serentak.

Implikasi sosial dari adanya Pilkada serentak ini diasumsikan akan lebih baik dibanding Pilkada sendiri-sendiri. Asumsi ini didasarkan atas kalkulasi kemungkinan menurunnya intensitas pemberitaan Pilkada yang selama ini muatannya relatif banyak yang negatif terutaa berkaitan dengan bentrokan sosial antar warga, politik uang, sengketa Pilkada dan lain-lain yang menyita perhatian warga terlalu banyak dan terlalu sering. Pilkada serentak setiaknya akan menurunkan intensitas pelaksanaan pilkada dan pada akahirnya tentu aja akan mengurangi intensitas pemberitaannya.

Secara politis, perubahan sistem Pilkada dari yang sebelumnya dilakukan secara parsial menjadi serentak tentu saja akan membawa dampak terutama pada bagaimana konstelasi politik yang dibangun oleh parpol dalam rangka memenangkan sebanyak mungkin kandidatanya di setiap daerah pemilihan. Dampak yang paling nyata adalah bahwa parpol besar sekalipun tidak bisa lagi mengerahkan seluruh kemampuannya untuk mendukung kemenangan kandidatnya di semua daerah pemilihan melalui dukungan kader-kader unggulan yang biasanya dikirimkan dari kantor pusat ke daerah. Masing-masing kandidat harus lebih banyak mengandalkan diri sendiri terutama ketokohannya untuk meraih simpati calon pemilih dibanding mengharapkan dukungan mesin-mesin partai pendukungnya. Oleh karena itu, diasumsikan Pilkada serentak ini akan lebih banyak memberi peluang kandidat jalur independen untuk menang dibanding yang melalui jalur partai politik.

Bahwa implikasi ekonomi pelaksanaan Pilkada serentak secara kalkulatif menunjukkan kondisi yang postitif dimana terlihat adanya penghematan yang signifikan antara biaya yang harus dikeluarkan negara untuk membayan Pilkada yang sendiri-sendiri dengan Pilkada serentak. Meskipun secara mikro masih harus diteliti dampak Pilkada serentak ini bagi perekonomian masyarakat di tingkat daerah karena bagaimanapun di dalam Pilkada ada belanja barang dan jasa ang berarti ada perputaran uang di dalam masyarakat oleh karena adanya Pilkada yang dilakukan secara serentak. 


\section{DAFTAR PUSTAKA}

Agustino, Leo. 2009. Pilkada dan Dinamika Politik Lokal. Yogyakarta: Pustaka Pelajar.

Bailusy, Muhammad Kausar. 2012. Politik Lokal dalam Sistem Otonomi Daerah. Jakarta: Mazhab Ciputat.

Budiardjo, Miriam. 2010. Dasar-Dasar Ilmu Politik: Edisi Revisi. Jakarta: Gramedia Pustaka Utama.

Efriza. 2012. Political Explore: Sebuah Kajian Ilmu Politik. Bandung: Penerbit Alfabeta.

MD, Moh. Mahfud. 2014. Politik Hukum di Indonesia. Jakarta: PT. RajaGrafindo Persada. 